ISSN: 1858-4837;E-ISSN: 2598-019X

Volume 16, Nomor 1 (2021)

https://jurnal.uns.ac.id/region

DOI: 10.20961/region.v16i1.35565

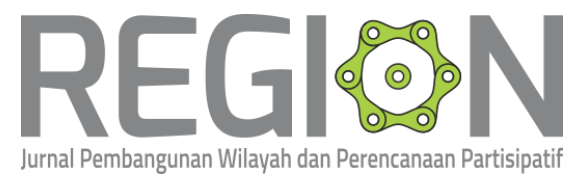

\title{
Hubungan place dependence terhadap keinginan alih fungsi lahan di Kecamatan Pandaan
}

\author{
Place dependence and land use change intention in Pandaan District, Indonesia
}

\author{
G Prayitno ${ }^{1}$, S A Rusmi ${ }^{1}$, D Dinanti ${ }^{1}$ \\ ${ }^{1}$ Regional and Urban Planning Department, Faculty of Engineering, Universitas \\ Brawijaya
}

Corresponding author's email: gunawan_p@ub.ac.id

\begin{abstract}
Abstrak. Alih fungsi lahan karena adanya pertambahan penduduk merupakan hal yang tidak dapat dielakkan dalam pengembangan wilayah. Perubahan penggunaan lahan dari lahan pertanian menjadi penggunaan lain misalnya permukiman, sarana perdagangan dan jasa, industry umumnya terjadi. Kecamatan Pandaan yang merupakan suatu kecamatan yang menghubungkan antara Kota Malang dan Kota Surabaya serta dilewati toll trans Jawa juga mengalami fenomena alih fungsi lahan pertanian ke non pertanian. Penelitian ini bertujuan untuk mengetahui bagaimana kondisi sosial masyarakat selain kondisi ekonomi dapat mempengaruhi keputusan masyarakat untuk melakukan alih fungsi lahan. Place dependence yang merupakan hubungan fungsional berdasarkan koneksi fisik individu dengan lingkungan dapat mempengaruhi keputusan alih fungsi lahan. Kami menggunakan analisa cross tabulasi untuk mengetahui hubungan place dependence dengan faktor pendorong aktivitas dalam sebuah tempat (lingkungan dimana tinggal). Place dependence digambarkan dengan pertanyaan dalam kuesioner sedangkan faktor pendorong aktivitas digambarkan dengan tingkat pendapatan, tempat beraktivitas dan kepemilikan lahan. Hasil analisa cross tabulasi menunjukkan bahwa hubungan place dependence dengan keputusan untuk mengubah lahan memiliki nilai signifikansi adalah 0,039 $(<0,05)$. Dengan demikian nilai tersebut menunjukkan bahwa place dependence memiliki hubungan dengan keputusan melakukan alih fungsi lahan.
\end{abstract}

Kata Kunci: Perubahan Lahan; Place Dependence

Abstract. Changes in land use due to population growth are inevitable in regional development. Land use changes from farmland to other uses such as settlements, commercial facilities and services, the industry usually occurs. The sub-district of 
Pandaan, which is a sub-district linking the cities of Malang and Surabaya and crossed by the Trans Java toll road, is also experiencing a phenomenon of conversion of agricultural land to non-agricultural land. This study aims to determine how the social conditions of the community, in addition to economic conditions, can influence the community's decision to change land functions. Place dependence, which is a functional relationship based on the physical connection of individuals with the environment, can affect land-use change decisions. We use a cross-tabulation analysis to determine the place dependence relationship with the determinants of activity in a place (the place where they live). The place dependence described by the questions in the questionnaire while the determining factors for the activities are described by the level of income, the place of activity and the property ownership of the land. The results of the cross-tabulation analysis showed relationship between place dependence and landowner decision to change their land has a significance value of $0.039(<0.05)$. Thus, this value indicated place dependence is related to the decision to transfer land functions.

Keywords: Land Use Change; Place Dependence

\section{Pendahuluan}

Kebutuhan lahan dari tahun ke tahun, dipengaruhi oleh bertambahnya jumlah penduduk dan meningkatnya kegiatan manusia. Selain itu, perkembangan ekonomi dan sosial juga meningkatkan kebutuhan akan permukiman dan infrastruktur yang dapat mendorong terjadinya alih fungsi lahan [1]. Penggunaan lahan memberikan pelayanan lingkungan yang kualitas dan kuantitasnya berubah seiring dengan kondisi sosial ekonomi, politik, budaya, yang dilakukan oleh manusia [2]. Salah satu kondisi sosial digambarkan dalam psikologi lingkungan. Place attachment muncul untuk memberikan pandangan terhadap cara orang untuk menanggapi suatu perubahan, yang dikonsepkan sebagai ikatan emosional antara manusia dan lingkungannya [3]. Salah satu dimensi dalam place attachment adalah place dependence. Place dependence memiliki arti yaitu hubungan fungsional berdasarkan koneksi secara fisik suatu individu pada suatu tempat sebagai contoh bagaimana suatu kondisi fisik suatu tempat dalam mendukung aktifitas [4].

Kabupaten Pasuruan wilayah yang mengalami perkembangan pesat. Berdasarkan aspek fisik, kabupaten Pasuruan merupakan kawasan strategis yang dilalui oleh sejumlah jaringan jalan utama yang berpotensi untuk mendorong perkembangan pada wilayah Kabupaten Pasuruan [5]. Adanya perkembangan yang terjadi, berdampak pada kegiatan alih fungsi lahan pada wilayah tersebut.

Salah satu bagian wilayah Kabupaten Pasuruan yang terkena dampak perubahan lahan adalah Kecamatan Pandaan. Kecamatan Pandaan merupakan salah satu kecamatan yang mengalami perkembangan akibat tumbuhnya jaringan jalan. Kecamatan Pandaan juga merupakan suatu kecamatan yang menghubungkan antara Kota Malang dan Kota Surabaya. Berdasarkan penelitian kami sebelumnya, alih fungsi lahan pertanian menjadi non pertanian terjadi secara cepat [6]. Alih fungsi lahan pada Kecamatan Pandaan berdampak pada kondisi sosial yaitu turunnya jumlah penduduk yang bekerja pada sektor pertanian [7]. 
Terjadinya alih fungsi lahan biasanya dipengaruhi oleh keputusan pemilik lahan. Sedangkan keputusan untuk melakukan alih fungsi lahan atau mempertahankan lahan juga di pengaruhi oleh hubungan pemilik lahan dengan tempat (place dependence). Penelitian ini bertujuan untuk mengetahui bagaimana kondisi hubungan place dependence pemilik lahan di Kecamatan Pandaan dengan keinginan untuk melakukan alih fungsi lahan.

\section{Metode}

Analisis crosstab merupakan analisis berbentuk tabel yang menampilkan suatu tabulasi silang yang menunjukkan adanya korelasi antara variabel satu dengan variabel yang lain. Analisis crosstab pada penelitian ini digunakan untuk mengetahui hubungan nilai place dependence dengan faktor pendorong aktivitas pada suatu tempat seperti tempat beraktivitas sehari-hari, bagaimana suatu tempat dapat memenuhi kebutuhan, dan kepemilikan lahan [8].

Crosstab terdiri dari antara baris (row) dan kolom (coloum). Crosstab berguna untuk menguji hubungan antara 2 variabel atau lebih. Dalam penelitian ini, tingkat place dependence diukur dengan pertanyaan dalam kuesioner berdasarkan indicator place dependence dari William and Vaske [4], sedangkan faktor yang mempengaruhi aktivitas suatu tempat diukur dengan tingkat pendapatan, sebagai tempat untuk melakukan aktivitas dan kepemilikan akan lahan tersebut (Tabel 1 dan Tabel 2).

Tabel 1. Uji hubungan yang akan dilaksanakan.

\begin{tabular}{ll}
\hline \multicolumn{1}{c}{ Indikator Place Dependence [4] } & Faktor yang Mempengaruhi Aktivitas \\
\hline Saya merasa lebih puas tinggaldi desa i ni da ripada di daerah lain & Tingkat Pendapatan \\
$\begin{array}{l}\text { Tidak ada tempat yangs ebanding dengan desa ini } \\
\text { Saya tidakingin menggantikan a ktivitas saya di desa ini untuk }\end{array}$ & Tempat Beraktivitas keseharian \\
dilakukan di tempat lain & Tempat Beraktivitas keseharian \\
$\begin{array}{l}\text { Mela kukan aktivitas di desa ini l ebih penting daripada melakukan di } \\
\text { tempat lai } n\end{array}$ & Tempat Beraktivitas keseharian \\
Desa ini adalah desa yang terbaik untukmelangsungkan aktivitas saya & Kepemilikan Lahan \\
\hline
\end{tabular}

Tabel 2. Uji hubungan berdasarkan place dependence.

\begin{tabular}{cl}
\hline Kode & \multicolumn{1}{c}{ Indikator Place Dependence [4] } \\
\hline A & Saya merasa lebih puas tinggaldi desa ini da ripada di daerah lain \\
B & Tidak ada tempat yangs ebanding dengan desa ini \\
C & Saya tidakingin menggantikana ktivitas saya di desa ini untuk dilakukan di tempat lain \\
D & Melakukan aktivitas di desa ini l ebih penting daripada melakukan di tempat lain \\
E & Desa ini adalah desa ya ng terbaik untukmel angsungkan aktivitas saya \\
\hline
\end{tabular}

Indikator place attachment dinyatakan dalam bentuk tingkat persetujuan dimana nilai yang dinyatakan adalah sebagai berikut.

$$
\begin{aligned}
& 1 \text { = sangat tidak setuju } \\
& 2 \text { = tidak penting } \\
& 3 \text { = cukup setuju } \\
& 4=\text { setuju } \\
& 5=\text { sangat setuju }
\end{aligned}
$$


Adapun variabel dalam faktor yang mempengaruhi place dependence dijabarkan pada Tabel 3.

Tabel 3. Uji hubungan berdasarkan tempat yang mempengaruhi aktivitas.

\begin{tabular}{|c|c|}
\hline Faktor yang Mempengaruhi & Parameter \\
\hline \multirow{5}{*}{ Tingkat Pendapatan } & $1:<\operatorname{Rp} 500.000,00$ \\
\hline & $2: \operatorname{Rp} 500.000,00-\operatorname{Rp} 1.000 .000,00$ \\
\hline & $3: \operatorname{Rp} 1.000 .000,00-\operatorname{Rp} 1.500 .000,00$ \\
\hline & $4: \operatorname{Rp} 1.500 .000,00-\operatorname{Rp} 2.000 .000,00$ \\
\hline & $5:>\operatorname{Rp} 2.000 .000,00$ \\
\hline \multirow{3}{*}{ Tempat Beraktivitas keseharian } & 1 : Di dalam desa/kelurahan saja \\
\hline & 2 : Di dalam dan luar desa/kelurahan \\
\hline & 3 : Di dalam dan luar kecamatan \\
\hline \multirow{6}{*}{ Kepemilikan Lahan } & $1: 0-0,49$ (ha) \\
\hline & 2: 0,5 - 0,99 (ha) \\
\hline & $3: 1-1,49$ (ha) \\
\hline & $4: 1,5-1,99$ (ha) \\
\hline & $5: 2-2,49$ (ha) \\
\hline & $6: 2,5-2,99$ (ha) \\
\hline
\end{tabular}

Keputusan untuk mengubah lahan dinyatakan dalam bentuk parameter dimana nilai 1 berarti 'Ya' dan nilai 2 berarti 'Tidak'.

Adapun langkah-langkah dalam pengujian chi square sebagai berikut:

1. Merumuskan hipotesis Ho dan $\mathrm{H} 1$

Ho : Tidak terdapat pengaruh yang signifikan antara dua variabel

$\mathrm{H} 1$ : Terdapat pengaruh yang signifikan antara dua variabel

2. Mencari nilai frekuensi harapan (ei)

e_i=(total baris)(total kolom)/(total keseluruhan)

3. Menghitung distribusi chisqure

4. Menentukan taraf signifikan $\alpha$

5. Menentukan nilai $\times 2$ tabel

Taraf signifikan $(\alpha)=0,05$

d.f $=($ Jumlah baris -1$)($ Jumlah kolom -1$)$

6. Menentukan kriteria pengujian

a. Jika $\times 2$ hitung $\leq \times 2$ tabel, maka Ho (Diterima)

b. Jika $\times 2$ hitung $>\times 2$ tabel, maka Ho (Ditolak)

c. Jika Sig. $\geq 0,05$, maka Ho (Diterima)

d. Jika Sig. <0,05, maka Ho (Ditolak)

7. Membandingkan $\times 2$ hitung dengan $\times 2$ tabel atau Sig. dengan $\alpha$ Keputusan Ho ditolak atau diterima

8. Membuat kesimpulan ada tidaknya pengaruh antar variabel

Penelitian ini menggunakan populasi yaitu kepala keluarga di Kecamatan Pandaan pada tahun 2017 sebanyak 30.930 KK yang terdapat pada setiap desa/kelurahan di Kecamatan Pandaan. 
Metode pengambilan sampel menggunakan metode purposive random sampling. Menurut Sugiyono [9], purposive sampling merupakan metode pengambilan sampel melalui pertimbangan tertentu. Riduwan [10] juga menjelaskan bahwa purposive random sampling menggunakan pertimbangan yang disusun oleh peneliti dalam pemilihan sampel. Pertimbangan sampel yang menjadi subjek penelitian adalah pemilik lahan yang tak terbangun. Pemilik lahan yang digunakan sebagai responden dapat berupa petani maupun non petani. Langkah untuk menentukan subjek sampel antara lain sebagai berikut.

1. Menentukan jumlah Kepala Keluarga (KK) di Kecamatan Pandaan

2. Menghitung luas lahan tak terbangun di setiap desa/kelurahan di Kecamatan Pandaan

3. Menghitung jumlah sampel dari seluruh kepala keluarga di Kecamatan Pandaan

4. Melakukan proporsi jumlah responden berdasarkan luas lahan yang tak terbangun di Kecamatan Pandaan

Setelah menghitung luas lahan tak terbangun, langkah selanjutnya yaitu melakukan perhitungan jumlah sampel dengan rumus Slovin dengan tingkat kesalahan sebanyak $10 \%$ karena merupakan penelitian sosial. Berikut ini adalah persamaan dan perhitungan metode Slovin.

$$
\mathrm{n}=\frac{N}{1+N e^{2}}
$$

\section{Keterangan:}

$$
\begin{array}{ll}
\mathrm{n} & =\text { jumlah sampel } \\
\mathrm{N} & =\text { populasi } \\
\mathrm{e} & =\text { margin error }(0,1)
\end{array}
$$

Berdasarkan rumus yang telah dijelaskan, jumlah sampel populasi di Kecamatan Pandaan adalah berikut.

$$
\begin{aligned}
& \mathrm{n}=\frac{30930}{1+\left(30930 \times 0,1^{2}\right)} \\
& \mathrm{n}=99,6 \sim 100
\end{aligned}
$$

Sampel yang diperoleh adalah 100 KK. Langkah selanjutnya yaitu mengidentifikasi kondisi place dependence di Kecamatan Pandaan melalui kuisioner dan variabel yang telah disiapkan.

\section{Hasil dan pembahasan}

Analisis yang dilakukan adalah bertujuan mengetahui hubungan masing-masing faktor yang mempengaruhi terhadap masing-masing pernyataan place dependence. Setiap hubungan dilakukan uji chi square sehingga menghasilkan satu persatu hubungan yang dikaji. Berikut ini adalah hasil pengukuran tingkat hubungan.

\subsection{Hubungan antara tingkat persetujuan pernyataan A: Saya merasa lebih puas tinggal di} desa ini daripada di daerah lain terhadap tingkat pendapatan

Hipotesa yang dibangun dalam uji hubungan ini adalah sebagai berikut. 
1. HO : Tidak terdapat antara tingkat persetujuan pernyataan A. Saya merasa lebih puas tinggal di desa ini daripada di daerah lain terhadap Tingkat Pendapatan.

2. H1 : Terdapat hubungan antara tingkat persetujuan pernyataan A. Saya merasa lebih puas tinggal di desa ini daripada di daerah lain terhadap Tingkat Pendapatan.

Berdasarkan hipotesa yang telah disusun, dapat dilakukan analisis crosstab dan uji chi square untuk menguji signifikansi hubungan. Tabel 4 adalah hasil interpretasi data hasil uji pada hubungan antara tingkat persetujuan pernyataan A: Saya merasa lebih puas tinggal di desa ini daripada di daerah lain terhadap Tingkat Pendapatan.

Tabel 4. Deskripsi hubungan antara tingkat persetujuan pernyataan A: Saya merasa lebih puas tinggal di desa ini daripada di daerah lain terhadap tingkat pendapatan.

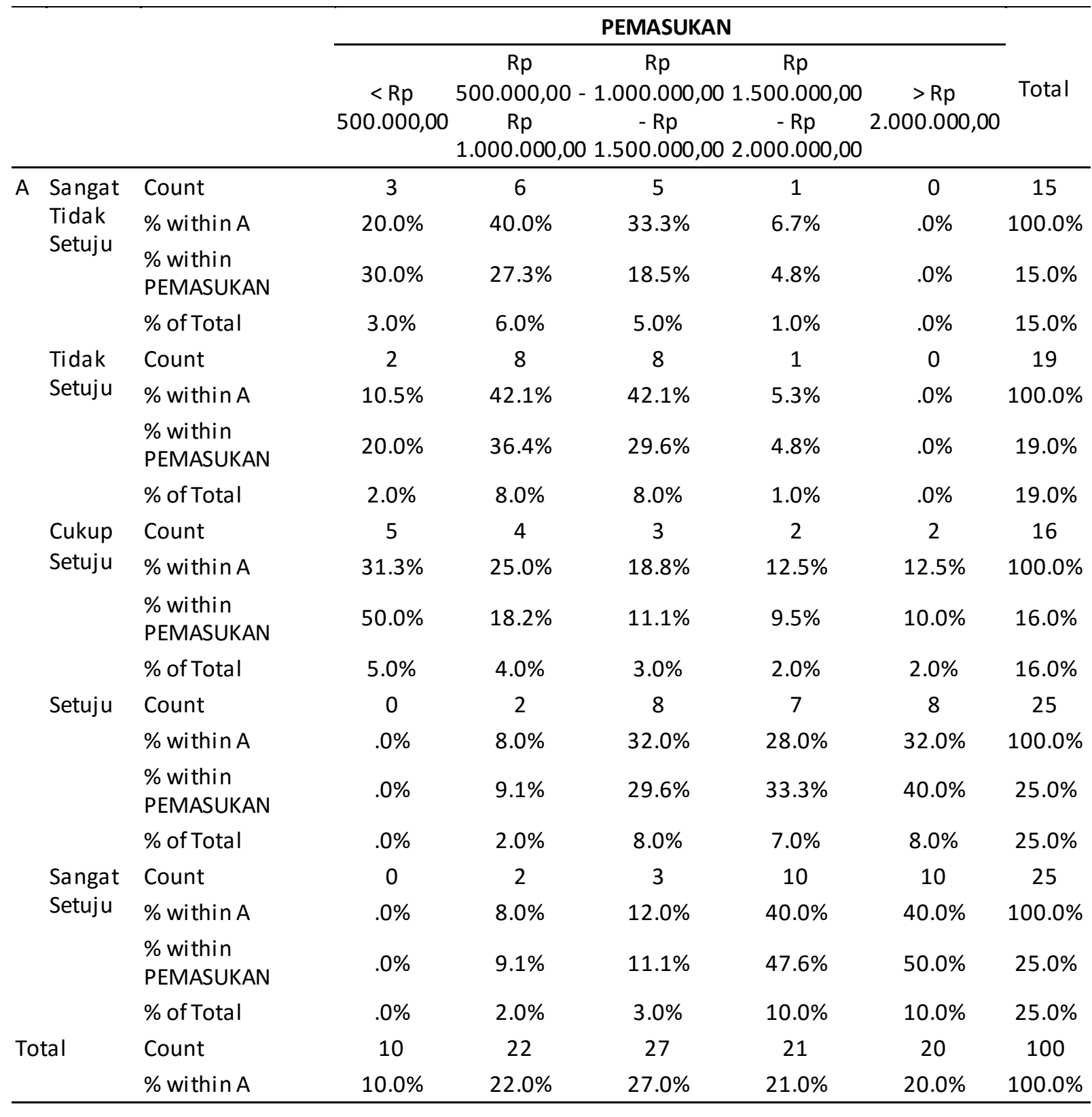

Received : November 13, 2019; Accepted: February 11, 2020; Available online: January 30, 2021 


\begin{tabular}{|c|c|c|c|c|c|c|}
\hline & \multicolumn{5}{|c|}{ PEMASUKAN } & \multirow[b]{2}{*}{ Total } \\
\hline & $\begin{array}{c}<\mathrm{Rp} \\
500.000,00\end{array}$ & $\begin{array}{c}R p \\
500.000,00- \\
R p \\
1.000 .000,00\end{array}$ & $\begin{array}{c}R p \\
1.000 .000,00 \\
-R p \\
1.500 .000,00\end{array}$ & $\begin{array}{c}R p \\
1.500 .000,00 \\
-R p \\
2.000 .000,00\end{array}$ & $\begin{array}{c}>R p \\
2.000 .000,00\end{array}$ & \\
\hline $\begin{array}{l}\% \text { within } \\
\text { PEMASUKAN }\end{array}$ & $100.0 \%$ & $100.0 \%$ & $100.0 \%$ & $100.0 \%$ & $100.0 \%$ & $100.0 \%$ \\
\hline$\%$ of Total & $10.0 \%$ & $22.0 \%$ & $27.0 \%$ & $21.0 \%$ & $20.0 \%$ & $100.0 \%$ \\
\hline
\end{tabular}

Berdasarkan hasil statistik deskriptif, dapat diketahui bahwa jumlah terbanyak adalah responden yang menyatakan setuju dan sangat setuju dengan tingkat pendapatan sebesar Rp 1.000.000,00 - Rp 1.500.000,00 dan Rp 1.500.000,00 - Rp 2.000.000,00. Hal tersebut menunjukkan bahwa responden memiliki tingkat place dependence yang tinggi seiring dengan pendapatan yang tinggi pula. Tabel 5 adalah hasil uji chi square yang dilakukan untuk mengetahui hubungan yang dihasilkan.

Tabel 5. Hasil uji hubungan antara tingkat persetujuan pernyataan A: Saya merasa lebih puas tinggal di desa ini daripada di daerah lain terhadap tingkat pendapatan.

\begin{tabular}{lccc}
\hline & Value & df & Asymp. Sig. (2-sided) \\
\hline Pearson Chi-Square & $51.686^{\mathrm{a}}$ & 16 & .000 \\
Likelihood Ratio & 60.410 & 16 & .000 \\
Linear-by-Linear As sociation & 34.758 & 1 & .000 \\
N of Valid Cases & 100 & & \\
\hline
\end{tabular}

Berdasarkan hasil uji yang disajikan, dapat diketahui bahwa nilai signifikansi adalah 0,000*, yaitu bernilai $<0,05$. Dengan demikian nilai tersebut menunjukkan bahwa $\mathrm{HO}$ ditolak atau terdapat hubungan antara tingkat persetujuan pernyataan A. Saya merasa lebih puas tinggal di desa ini daripada di daerah lain terhadap Tingkat Pendapatan. Kesimpulan yang diperoleh menunjukkan bahwa pemilik lahan memiliki keterikatan yang tinggi terhadap lahan yang mereka miliki seiring dengan tingginya pendapatan yang mereka peroleh.

\subsection{Hubungan antara tingkat persetujuan pernyataan B: Tidak ada tempat yang sebanding} dengan desa ini terhadap lokasi melakukan aktivitas sehari-hari

Hipotesa yang dibangun dalam uji hubungan ini adalah sebagai berikut.

1. HO : Tidak terdapat antara tingkat persetujuan pernyataan B. Tidak ada tempat yang sebanding dengan desa ini terhadap lokasi melakukan aktivitas sehari-hari.

2. H1 : Terdapat hubungan antara tingkat persetujuan pernyataan B. Tidak ada tempat yang sebanding dengan desa ini terhadap lokasi melakukan aktivitas sehari-hari.

Berdasarkan hipotesa yang telah disusun, dapat dilakukan analisis crosstab dan uji chi square untuk menguji signifikansi hubungan. Tabel 6 adalah hasil interpretasi data hasil uji pada hubungan antara tingkat persetujuan pernyataan B: Tidak ada tempat yang sebanding dengan desa ini terhadap lokasi melakukan aktivitas sehari-hari. 
Tabel 6. Deskripsi hubungan antara tingkat persetujuan pernyataan B: Tidak ada tempat yang sebanding dengan desa ini terhadap lokasi melakukan aktivitas sehari-hari.

\begin{tabular}{|c|c|c|c|c|c|c|}
\hline & & & \multicolumn{3}{|c|}{ AKTIVITAS } & \multirow[b]{2}{*}{ Total } \\
\hline & & & $\begin{array}{c}\text { Di dalam } \\
\text { desa/kelurahansaja }\end{array}$ & $\begin{array}{c}\text { Di dalam dan luar } \\
\text { desa/kel urahan }\end{array}$ & $\begin{array}{c}\text { Di dalam dan luar } \\
\text { kecamatan }\end{array}$ & \\
\hline \multirow[t]{20}{*}{ B } & \multirow{4}{*}{$\begin{array}{l}\text { Sangat } \\
\text { Tidak } \\
\text { Setuju }\end{array}$} & Count & 0 & 5 & 6 & 11 \\
\hline & & $\%$ within B & $.0 \%$ & $45.5 \%$ & $54.5 \%$ & $100.0 \%$ \\
\hline & & \% within AKTIVITAS & $.0 \%$ & $13.5 \%$ & $27.3 \%$ & $11.0 \%$ \\
\hline & & $\%$ of Total & $.0 \%$ & $5.0 \%$ & $6.0 \%$ & $11.0 \%$ \\
\hline & \multirow{4}{*}{$\begin{array}{l}\text { Tidak } \\
\text { Setuju }\end{array}$} & Count & 4 & 9 & 10 & 23 \\
\hline & & $\%$ within B & $17.4 \%$ & $39.1 \%$ & $43.5 \%$ & $100.0 \%$ \\
\hline & & $\%$ within AKTIVITAS & $9.8 \%$ & $24.3 \%$ & $45.5 \%$ & $23.0 \%$ \\
\hline & & $\%$ of Total & $4.0 \%$ & $9.0 \%$ & $10.0 \%$ & $23.0 \%$ \\
\hline & \multirow{4}{*}{$\begin{array}{l}\text { Cukup } \\
\text { Setuju }\end{array}$} & Count & 2 & 7 & 5 & 14 \\
\hline & & $\%$ within B & $14.3 \%$ & $50.0 \%$ & $35.7 \%$ & $100.0 \%$ \\
\hline & & $\%$ within AKTIVITAS & $4.9 \%$ & $18.9 \%$ & $22.7 \%$ & $14.0 \%$ \\
\hline & & $\%$ of Total & $2.0 \%$ & $7.0 \%$ & $5.0 \%$ & $14.0 \%$ \\
\hline & \multirow[t]{4}{*}{ Setuju } & Count & 18 & 8 & 0 & 26 \\
\hline & & $\%$ within B & $69.2 \%$ & $30.8 \%$ & $.0 \%$ & $100.0 \%$ \\
\hline & & \% within AKTIVITAS & $43.9 \%$ & $21.6 \%$ & $.0 \%$ & $26.0 \%$ \\
\hline & & $\%$ of Total & $18.0 \%$ & $8.0 \%$ & $.0 \%$ & $26.0 \%$ \\
\hline & \multirow{4}{*}{$\begin{array}{l}\text { Sangat } \\
\text { Setuju }\end{array}$} & Count & 17 & 8 & 1 & 26 \\
\hline & & $\%$ within B & $65.4 \%$ & $30.8 \%$ & $3.8 \%$ & $100.0 \%$ \\
\hline & & $\%$ within AKTIVITAS & $41.5 \%$ & $21.6 \%$ & $4.5 \%$ & $26.0 \%$ \\
\hline & & $\%$ of Total & $17.0 \%$ & $8.0 \%$ & $1.0 \%$ & $26.0 \%$ \\
\hline \multirow[t]{4}{*}{ Total } & & Count & 41 & 37 & 22 & 100 \\
\hline & & $\%$ within B & $41.0 \%$ & $37.0 \%$ & $22.0 \%$ & $100.0 \%$ \\
\hline & & $\%$ within AKTIVITAS & $100.0 \%$ & $100.0 \%$ & $100.0 \%$ & $100.0 \%$ \\
\hline & & $\%$ of Total & $41.0 \%$ & $37.0 \%$ & $22.0 \%$ & $100.0 \%$ \\
\hline
\end{tabular}

Berdasarkan hasil statistik deskriptif, dapat diketahui bahwa jumlah terbanyak adalah responden yang menyatakan setuju dan sangat setuju dengan tingkat aktivitas yang dilakukan adalah di dalam desa. Hal tersebut menunjukkan bahwa responden menyatakan place dependence yang tinggi seiring dengan intensitas kegiatan yang dilakukan di dalam desa. Tabel 7 adalah hasil uji chi square yang dilakukan untuk mengetahui hubungan yang dihasilkan.

Tabel 7. Hasi uji hubungan antara tingkat persetujuan pernyataan B: Tidak ada tempat yang sebanding dengan desa ini terhadap lokasi melakukan aktivitas sehari-hari.

\begin{tabular}{lccc}
\hline & Value & df & Asymp. Sig. (2-sided) \\
\hline PearsonChi-Square & $41.255^{\mathrm{a}}$ & 8 & .000 \\
Likelihood Ratio & 50.907 & 8 & .000 \\
\hline
\end{tabular}




\begin{tabular}{lccc}
\hline & Value & df & Asymp. Sig. (2-sided) \\
\hline Linear-by-Linear Association & 34.131 & 1 & .000 \\
N of Valid Cases & 100 & & \\
\hline
\end{tabular}

Berdasarkan hasil uji yang disajikan, dapat diketahui bahwa nilai signifikansi adalah 0,000*, yaitu bernilai $<0,05$. Dengan demikian nilai tersebut menunjukkan bahwa HO ditolak atau terdapat hubungan antara tingkat persetujuan pernyataan B. Tidak ada tempat yang sebanding dengan desa ini terhadap lokasi melakukan aktivitas sehari-hari. Kesimpulan yang diperoleh menunjukkan bahwa pemilik lahan memiliki keterikatan tempat terhadap lahan yang dimiliki seiring dengan intensitas kegiatan yang mereka lakukan pada lahan tersebut.

3.3 Hubungan antara tingkat persetujuan pernyataan C: Saya tidak ingin menggantikan aktivitas saya di desa ini untuk dilakukan di tempat lain terhadap lokasi melakukan aktivitas sehari-hari

Hipotesa yang dibangun dalam uji hubungan ini adalah sebagai berikut.

1. HO : Tidak terdapat hubungan antara tingkat persetujuan pernyataan C. Saya tidak ingin menggantikan aktivitas saya di desa ini untuk dilakukan di tempat lain terhadap lokasi melakukan aktivitas sehari-hari.

2. H1 : Terdapat hubungan antara tingkat persetujuan pernyataan C. Saya tidak ingin menggantikan aktivitas saya di desa ini untuk dilakukan di tempat lain terhadap lokasi melakukan aktivitas sehari-hari.

Berdasarkan hipotesa yang telah disusun, dapat dilakukan analisis crosstab dan uji chisquare untuk menguji signifikansi hubungan. Tabel 8 adalah hasil interpretasi data hasil uji pada hubungan antara tingkat persetujuan pernyataan C: Saya tidak ingin menggantikan aktivitas saya di desa ini untuk dilakukan di tempat lain terhadap lokasi melakukan aktivitas seharihari.

Tabel 8. Deskripsi hubungan antara tingkat persetujuan pernyataan C. Saya tidak ingin menggantikan aktivitas saya di desa ini untuk dilakukan di tempat lain terhadap lokasi melakukan aktivitas sehari-hari.

\begin{tabular}{|c|c|c|c|c|c|c|}
\hline & & & \multicolumn{3}{|c|}{ AKTIVITAS } & \multirow[b]{2}{*}{ Total } \\
\hline & & & $\begin{array}{l}\text { Di dalam desa/ } \\
\text { kel urahan saja }\end{array}$ & $\begin{array}{c}\text { Di dalam dan luar } \\
\text { desa/kelurahan }\end{array}$ & $\begin{array}{l}\text { Di dalam dan luar } \\
\text { kecamatan }\end{array}$ & \\
\hline \multirow[t]{9}{*}{ C } & Sangat & Count & 1 & 5 & 5 & 11 \\
\hline & \multirow{3}{*}{$\begin{array}{l}\text { Tidak } \\
\text { Setuju }\end{array}$} & $\%$ within C & $9.1 \%$ & $45.5 \%$ & $45.5 \%$ & $100.0 \%$ \\
\hline & & $\%$ within AKTIVITAS & $2.4 \%$ & $13.5 \%$ & $22.7 \%$ & $11.0 \%$ \\
\hline & & $\%$ of Total & $1.0 \%$ & $5.0 \%$ & $5.0 \%$ & $11.0 \%$ \\
\hline & \multirow{4}{*}{$\begin{array}{l}\text { Tidak } \\
\text { Setuju }\end{array}$} & Count & 4 & 10 & 9 & 23 \\
\hline & & $\%$ within C & $17.4 \%$ & $43.5 \%$ & $39.1 \%$ & $100.0 \%$ \\
\hline & & \% within AKTIVITAS & $9.8 \%$ & $27.0 \%$ & $40.9 \%$ & $23.0 \%$ \\
\hline & & $\%$ of Total & $4.0 \%$ & $10.0 \%$ & $9.0 \%$ & $23.0 \%$ \\
\hline & Cukup & Count & 7 & 4 & 5 & 16 \\
\hline
\end{tabular}




\begin{tabular}{clcccc}
\hline & & \multicolumn{3}{c}{ AKTIVITAS } & \\
\cline { 3 - 5 } & & $\begin{array}{c}\text { Di dalam desa/ } \\
\text { kelurahan saja }\end{array}$ & $\begin{array}{c}\text { Di dalam dan luar } \\
\text { desa/kelurahan }\end{array}$ & $\begin{array}{c}\text { Di dalam dan luar } \\
\text { kecamatan }\end{array}$ & Total \\
\hline \multirow{2}{*}{ Setuju } & \% within C & $43.8 \%$ & $25.0 \%$ & $31.3 \%$ & $100.0 \%$ \\
& \% within AKTIVITAS & $17.1 \%$ & $10.8 \%$ & $22.7 \%$ & $16.0 \%$ \\
& \% of Total & $7.0 \%$ & $4.0 \%$ & $5.0 \%$ & $16.0 \%$ \\
\cline { 2 - 5 } Setuju & Count & 16 & 11 & 0 & 27 \\
& \% within C & $59.3 \%$ & $40.7 \%$ & $.0 \%$ & $100.0 \%$ \\
& \% within AKTIVITAS & $39.0 \%$ & $29.7 \%$ & $.0 \%$ & $27.0 \%$ \\
& \% of Total & $16.0 \%$ & $11.0 \%$ & $.0 \%$ & $27.0 \%$ \\
Sangat & Count & 13 & 7 & 3 & 23 \\
& \% within C & $56.5 \%$ & $30.4 \%$ & $13.0 \%$ & $100.0 \%$ \\
& \% within AKTIVITAS & $31.7 \%$ & $18.9 \%$ & $13.6 \%$ & $23.0 \%$ \\
& \% of Total & $13.0 \%$ & $7.0 \%$ & $3.0 \%$ & $23.0 \%$ \\
& Count & 41 & 37 & 22 & 100 \\
& \% within C & $41.0 \%$ & $37.0 \%$ & $22.0 \%$ & $100.0 \%$ \\
& \% within AKTIVITAS & $100.0 \%$ & $100.0 \%$ & $100.0 \%$ & $100.0 \%$ \\
& \% of Total & $41.0 \%$ & $37.0 \%$ & $22.0 \%$ & $100.0 \%$ \\
\hline
\end{tabular}

Berdasarkan hasil statistik deskriptif, dapat diketahui bahwa jumlah terbanyak adalah responden yang menyatakan sangat setuju dengan tingkat aktivitas yang dilakukan adalah di dalam desa. Hal tersebut menunjukkan bahwa responden menyatakan place dependence yang tinggi seiring dengan intensitas kegiatan yang dilakukan di dalam desa. Tabel 9 adalah hasil uji chi square yang dilakukan untuk mengetahui hubungan yang dihasilkan.

Tabel 9. Hasi uji hubungan antara tingkat persetujuan pernyataan C: Saya tidak ingin menggantikan aktivitas saya di desa ini untuk dilakukan di tempat lain terhadap lokasi melakukan aktivitas sehari-hari.

\begin{tabular}{lccc}
\hline & Value & df & Asymp. Sig. (2-sided) \\
\hline Pearson Chi-Square & $24.121^{\mathrm{a}}$ & 8 & .002 \\
Likelihood Ratio & 30.698 & 8 & .000 \\
Linear-by-Linear Association & 17.852 & 1 & .000 \\
N of Valid Cases & 100 & & \\
\hline
\end{tabular}

Berdasarkan hasil uji yang disajikan, dapat diketahui bahwa nilai signifikansi adalah 0,002, yaitu bernilai $<0,05$. Dengan demikian nilai tersebut menunjukkan bahwa HO ditolak atau terdapat hubungan antara tingkat persetujuan pernyataan C: Saya tidak ingin menggantikan aktivitas saya di desa ini untuk dilakukan di tempat lain terhadap lokasi melakukan aktivitas sehari-hari. Kesimpulan yang diperoleh menunjukkan bahwa pemilik lahan cenderung merasa nyaman untuk melakukan aktivitas pada tempat yang mereka tinggali sehingga tidak ingin melakukannya di tempat lain. Hal tersebut berkaitan dengan kegiatan bertani yang mereka lakukan setiap hari. 
3.4 Hubungan antara tingkat persetujuan pernyataan D: Melakukan aktivitas di desa ini lebih penting daripada melakukan di tempat lain terhadap lokasi melakukan aktivitas sehari-hari

Hipotesa yang dibangun dalam uji hubungan ini adalah sebagai berikut.

1. HO : Tidak terdapat antara tingkat persetujuan pernyataan D. Melakukan aktivitas di desa ini lebih penting daripada melakukan di tempat lain terhadap lokasi melakukan aktivitas sehari-hari.

2. H1 : Terdapat antara tingkat persetujuan pernyataan D. Melakukan aktivitas di desa ini lebih penting daripada melakukan di tempat lain terhadap lokasi melakukan aktivitas sehari-hari.

Berdasarkan hipotesa yang telah disusun, dapat dilakukan analisis crosstab dan uji chi square untuk menguji signifikansi hubungan. Tabel 10 adalah hasil interpretasi data hasil uji pada hubungan antara tingkat persetujuan pernyataan D: Melakukan aktivitas di desa ini lebih penting daripada melakukan di tempat lain terhadap lokasi melakukan aktivitas sehari-hari.

Tabel 10. Deskripsi hubungan antara tingkat persetujuan pernyataan D: Melakukan aktivitas di desa ini lebih penting daripada melakukan di tempat lain terhadap lokasi melakukan aktivitas sehari-hari.

\begin{tabular}{|c|c|c|c|c|c|c|}
\hline & & & \multicolumn{3}{|c|}{ AKTIVITAS } & \multirow[b]{2}{*}{ Total } \\
\hline & & & $\begin{array}{l}\text { Di dalam desa/ } \\
\text { kelurahan saja }\end{array}$ & $\begin{array}{c}\text { Di dalam dan luar } \\
\text { desa/kel urahan }\end{array}$ & $\begin{array}{c}\text { Di dalam dan luar } \\
\text { kecamatan }\end{array}$ & \\
\hline \multirow[t]{20}{*}{ 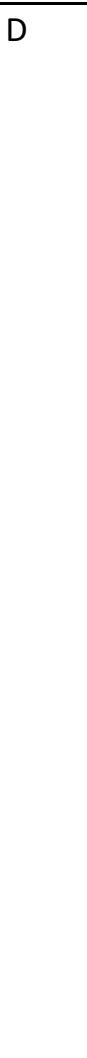 } & \multirow{4}{*}{$\begin{array}{l}\text { Sangat } \\
\text { Tidak } \\
\text { Setuju }\end{array}$} & Count & 4 & 5 & 7 & 16 \\
\hline & & \% within D & $25.0 \%$ & $31.3 \%$ & $43.8 \%$ & $100.0 \%$ \\
\hline & & \% within AKTIVITAS & $9.8 \%$ & $13.5 \%$ & $31.8 \%$ & $16.0 \%$ \\
\hline & & $\%$ of Total & $4.0 \%$ & $5.0 \%$ & $7.0 \%$ & $16.0 \%$ \\
\hline & \multirow{4}{*}{$\begin{array}{l}\text { Tidak } \\
\text { Setuju }\end{array}$} & Count & 5 & 10 & 12 & 27 \\
\hline & & \% within D & $18.5 \%$ & $37.0 \%$ & $44.4 \%$ & $100.0 \%$ \\
\hline & & $\%$ within AKTIVITAS & $12.2 \%$ & $27.0 \%$ & $54.5 \%$ & $27.0 \%$ \\
\hline & & $\%$ of Total & $5.0 \%$ & $10.0 \%$ & $12.0 \%$ & $27.0 \%$ \\
\hline & \multirow{4}{*}{$\begin{array}{l}\text { Cukup } \\
\text { Setuju }\end{array}$} & Count & 8 & 9 & 3 & 20 \\
\hline & & \% within D & $40.0 \%$ & $45.0 \%$ & $15.0 \%$ & $100.0 \%$ \\
\hline & & \% within AKTIVITAS & $19.5 \%$ & $24.3 \%$ & $13.6 \%$ & $20.0 \%$ \\
\hline & & $\%$ of Total & $8.0 \%$ & $9.0 \%$ & $3.0 \%$ & $20.0 \%$ \\
\hline & \multirow[t]{4}{*}{ Setuju } & Count & 8 & 7 & 0 & 15 \\
\hline & & \% within D & $53.3 \%$ & $46.7 \%$ & $.0 \%$ & $100.0 \%$ \\
\hline & & $\%$ within AKTIVITAS & $19.5 \%$ & $18.9 \%$ & $.0 \%$ & $15.0 \%$ \\
\hline & & $\%$ of Total & $8.0 \%$ & $7.0 \%$ & $.0 \%$ & $15.0 \%$ \\
\hline & \multirow{4}{*}{$\begin{array}{l}\text { Sangat } \\
\text { Setuju }\end{array}$} & Count & 16 & 6 & 0 & 22 \\
\hline & & \% within D & $72.7 \%$ & $27.3 \%$ & $.0 \%$ & $100.0 \%$ \\
\hline & & $\%$ within AKTIVITAS & $39.0 \%$ & $16.2 \%$ & $.0 \%$ & $22.0 \%$ \\
\hline & & $\%$ of Total & $16.0 \%$ & $6.0 \%$ & $.0 \%$ & $22.0 \%$ \\
\hline Total & & Count & 41 & 37 & 22 & 100 \\
\hline
\end{tabular}




\begin{tabular}{lcccc}
\hline & \multicolumn{4}{c}{ AKTIVITAS } \\
\cline { 2 - 4 } & $\begin{array}{c}\text { Di dalam desa/ } \\
\text { kelurahan saja }\end{array}$ & $\begin{array}{c}\text { Di dalam dan Iuar } \\
\text { desa/kelurahan }\end{array}$ & $\begin{array}{c}\text { Di dalam dan luar } \\
\text { kecamatan }\end{array}$ & Total \\
\hline \% within D & $41.0 \%$ & $37.0 \%$ & $22.0 \%$ & $100.0 \%$ \\
\% within AKTIVITAS & $100.0 \%$ & $100.0 \%$ & $100.0 \%$ & $100.0 \%$ \\
\% of Total & $41.0 \%$ & $37.0 \%$ & $22.0 \%$ & $100.0 \%$ \\
\hline
\end{tabular}

Berdasarkan hasil statistik deskriptif, dapat diketahui bahwa jumlah terbanyak adalah responden yang menyatakan tidak setuju dengan tingkat aktivitas yang dilakukan adalah di dalam desa. Hal tersebut menunjukkan bahwa responden menyatakan bahwa kegiatan di dalam desa belum tentu lebih penting dibandingkan di luar desa. Untuk menguji hubungan secara lebih lanjut, Tabel 11 adalah hasil uji chi square yang dilakukan untuk mengetahui hubungan yang dihasilkan.

Tabel 11. Hasi uji hubungan antara tingkat persetujuan pernyataan D: Melakukan aktivitas di desa ini lebih penting daripada melakukan di tempat lain terhadap lokasi melakukan aktivitas sehari-hari.

\begin{tabular}{lccc}
\hline & Value & df & Asymp. Sig. (2-sided) \\
\hline Pearson Chi-Square & $29.929^{\mathrm{a}}$ & 8 & .000 \\
Likelihood Ratio & 35.894 & 8 & .000 \\
Linear-by-Linear Association & 24.136 & 1 & .000 \\
N of Valid Cases & 100 & & \\
\hline
\end{tabular}

Berdasarkan hasil uji yang disajikan, dapat diketahui bahwa nilai signifikansi adalah 0,000*, yaitu bernilai $<0,05$. Dengan demikian nilai tersebut menunjukkan bahwa HO ditolak atau terdapat hubungan antara tingkat persetujuan pernyataan D: Melakukan aktivitas di desa ini lebih penting daripada melakukan di tempat lain terhadap lokasi melakukan aktivitas seharihari. Hal tersebut disebabkan oleh jumlah pernyataan setuju dan sangat setuju mendominasi dan membuktikan adanya hubungan antara tingkat persetujuan pernyataan D: Melakukan aktivitas di desa ini lebih penting daripada melakukan di tempat lain terhadap lokasi melakukan aktivitas sehari-hari. Kesimpulan yang diperoleh menunjukkan bahwa adanya intensitas aktivitas yang dilakukan terus-menerus membuat pemilik lahan merasa aktivitas yang dilakukan menjadi penting sehingga meningkatkan keterikatan pada tempat tersebut.

\subsection{Hubungan antara tingkat persetujuan pernyataan E: Desa ini adalah desa yang terbaik untuk melangsungkan aktivitas saya terhadap luas lahan yang dimiliki}

Hipotesa yang dibangun dalam uji hubungan ini adalah sebagai berikut.

1. HO : Tidak terdapat hubungan antara tingkat persetujuan pernyataan E. Desa ini adalah desa yang terbaik untuk melangsungkan aktivitas saya te rhadap luas lahan yang dimiliki.

2. H1 : Terdapat hubungan antara tingkat persetujuan pernyataan E. Desa ini adalah desa yang terbaik untuk melangsungkan aktivitas saya terhadap luas lahan yang dimiliki.

Berdasarkan hipotesa yang telah disusun, dapat dilakukan analisis crosstab dan uji chi square untuk menguji signifikansi hubungan. Tabel 12 adalah hasil interpretasi data hasil uji pada 
hubungan antara tingkat persetujuan pernyataan E: Desa ini adalah desa yang terbaik untuk melangsungkan aktivitas saya terhadap luas lahan yang dimiliki.

Tabel 12. Deskripsi hubungan antara tingkat persetujuan pernyataan E: Desa ini adalah desa yang terbaik untuk melangsungkan aktivitas saya terhadap luas lahan yang dimiliki.

\begin{tabular}{|c|c|c|c|c|c|c|c|c|c|}
\hline & & & \multicolumn{6}{|c|}{ LUAS LAHAN } & \multirow[b]{2}{*}{ Total } \\
\hline & & & $\begin{array}{c}0-0,49 \\
\text { (ha }\end{array}$ & $\begin{array}{c}0,5-0,99 \\
\text { (ha) }\end{array}$ & $\begin{array}{c}1-1,49 \\
\text { (ha) }\end{array}$ & $\begin{array}{c}1,5-1,99 \\
\text { (ha) }\end{array}$ & $\begin{array}{c}2-2,49 \\
\text { (ha) }\end{array}$ & $\begin{array}{c}2,5-2,99 \\
\text { (ha) }\end{array}$ & \\
\hline \multirow[t]{20}{*}{$E$} & \multicolumn{2}{|c|}{ Sangat Count } & 3 & 7 & 1 & 0 & 0 & 0 & 11 \\
\hline & \multirow{3}{*}{$\begin{array}{l}\text { Tidak } \\
\text { Setuju }\end{array}$} & $\%$ within $\mathrm{E}$ & $27.3 \%$ & $63.6 \%$ & $9.1 \%$ & $.0 \%$ & $.0 \%$ & $.0 \%$ & $100.0 \%$ \\
\hline & & $\%$ within LUAS_LAHAN & $17.6 \%$ & $25.0 \%$ & $5.0 \%$ & $.0 \%$ & $.0 \%$ & $.0 \%$ & $11.0 \%$ \\
\hline & & $\%$ of Total & $3.0 \%$ & $7.0 \%$ & $1.0 \%$ & $.0 \%$ & $.0 \%$ & $.0 \%$ & $11.0 \%$ \\
\hline & \multirow{4}{*}{$\begin{array}{l}\text { Tidak } \\
\text { Setuju }\end{array}$} & Count & 8 & 8 & 4 & 1 & 1 & 0 & 22 \\
\hline & & $\%$ within $\mathrm{E}$ & $36.4 \%$ & $36.4 \%$ & $18.2 \%$ & $4.5 \%$ & $4.5 \%$ & $.0 \%$ & $100.0 \%$ \\
\hline & & $\%$ within LUAS_LAHAN & $47.1 \%$ & $28.6 \%$ & $20.0 \%$ & $5.6 \%$ & $14.3 \%$ & $.0 \%$ & $22.0 \%$ \\
\hline & & $\%$ of Total & $8.0 \%$ & $8.0 \%$ & $4.0 \%$ & $1.0 \%$ & $1.0 \%$ & $.0 \%$ & $22.0 \%$ \\
\hline & \multirow{4}{*}{$\begin{array}{l}\text { Cukup } \\
\text { Setuju }\end{array}$} & Count & 2 & 5 & 4 & 3 & 0 & 0 & 14 \\
\hline & & $\%$ within $\mathrm{E}$ & $14.3 \%$ & $35.7 \%$ & $28.6 \%$ & $21.4 \%$ & $.0 \%$ & $.0 \%$ & $100.0 \%$ \\
\hline & & $\%$ within LUAS_LAHAN & $11.8 \%$ & $17.9 \%$ & $20.0 \%$ & $16.7 \%$ & $.0 \%$ & $.0 \%$ & $14.0 \%$ \\
\hline & & $\%$ of Total & $2.0 \%$ & $5.0 \%$ & $4.0 \%$ & $3.0 \%$ & $.0 \%$ & $.0 \%$ & $14.0 \%$ \\
\hline & \multirow[t]{4}{*}{ Setuju } & Count & 3 & 1 & 5 & 7 & 3 & 8 & 27 \\
\hline & & $\%$ within $\mathrm{E}$ & $11.1 \%$ & $3.7 \%$ & $18.5 \%$ & $25.9 \%$ & $11.1 \%$ & $29.6 \%$ & $100.0 \%$ \\
\hline & & $\%$ within LUAS_LAHAN & $17.6 \%$ & $3.6 \%$ & $25.0 \%$ & $38.9 \%$ & $42.9 \%$ & $80.0 \%$ & $27.0 \%$ \\
\hline & & $\%$ of Total & $3.0 \%$ & $1.0 \%$ & $5.0 \%$ & $7.0 \%$ & $3.0 \%$ & $8.0 \%$ & $27.0 \%$ \\
\hline & \multirow{4}{*}{$\begin{array}{l}\text { Sangat } \\
\text { Setuju }\end{array}$} & Count & 1 & 7 & 6 & 7 & 3 & 2 & 26 \\
\hline & & $\%$ within $E$ & $3.8 \%$ & $26.9 \%$ & $23.1 \%$ & $26.9 \%$ & $11.5 \%$ & $7.7 \%$ & $100.0 \%$ \\
\hline & & $\%$ within LUAS_LAHAN & $5.9 \%$ & $25.0 \%$ & $30.0 \%$ & $38.9 \%$ & $42.9 \%$ & $20.0 \%$ & $26.0 \%$ \\
\hline & & $\%$ of Total & $1.0 \%$ & $7.0 \%$ & $6.0 \%$ & $7.0 \%$ & $3.0 \%$ & $2.0 \%$ & $26.0 \%$ \\
\hline \multirow{4}{*}{\multicolumn{2}{|c|}{ Total }} & Count & 17 & 28 & 20 & 18 & 7 & 10 & 100 \\
\hline & & $\%$ within $\mathrm{E}$ & $17.0 \%$ & $28.0 \%$ & $20.0 \%$ & $18.0 \%$ & $7.0 \%$ & $10.0 \%$ & $100.0 \%$ \\
\hline & & $\%$ within LUAS_LAHAN & $100.0 \%$ & $100.0 \%$ & $100.0 \%$ & $100.0 \%$ & $100.0 \%$ & $100.0 \%$ & $100.0 \%$ \\
\hline & & $\%$ of Total & $17.0 \%$ & $28.0 \%$ & $20.0 \%$ & $18.0 \%$ & $7.0 \%$ & $10.0 \%$ & $100.0 \%$ \\
\hline
\end{tabular}

Berdasarkan hasil statistik deskriptif, dapat diketahui bahwa jumlah terbanyak adalah responden yang menyatakan setuju dengan luas lahan yang dimiliki adalah sebanyak $0,5-1$ hektar. Hal tersebut menunjukkan bahwa responden yang menyatakan desa yang terbaik untuk melangsungkan aktivitas memiliki luas lahan yang relatif luas.

\subsection{Hubungan antara tingkat persetujuan place dependence dengan keputusan untuk mengubah lahan}

Hipotesa yang dibangun dalam uji hubungan ini adalah sebagai berikut.

1. HO : Tidak terdapat hubungan antara tingkat persetujuan place dependence dengan keputusan untuk mengubah lahan. 
2. H1 : Terdapat hubungan antara tingkat persetujuan place dependence dengan keputusan untuk mengubah lahan.

Berdasarkan hipotesa yang telah disusun, dapat dilakukan analisis crosstab dan uji chi square untuk menguji signifikansi hubungan. Tabel 13 adalah hasil interpretasi data hasil uji pada hubungan antara tingkat persetujuan place dependence dengan keputusan untuk mengubah lahan.

Tabel 13. Deskripsi hubungan antara tingkat persetujuan place dependence dengan keputusan untuk mengubah lahan.

\begin{tabular}{|c|c|c|c|c|c|}
\hline & & & \multicolumn{2}{|c|}{ KEPUTUSAN } & \multirow[b]{2}{*}{ Total } \\
\hline & & & $\mathrm{Ya}$ & Tidak & \\
\hline \multirow[t]{20}{*}{ RERATA_PD } & SangatTidakSetuju & Count & 3 & 1 & 4 \\
\hline & & $\%$ within RERATA_PD & $75.0 \%$ & $25.0 \%$ & $100.0 \%$ \\
\hline & & $\%$ within KEPUTUSAN & $7.5 \%$ & $1.7 \%$ & $4.0 \%$ \\
\hline & & $\%$ of Total & $3.0 \%$ & $1.0 \%$ & $4.0 \%$ \\
\hline & Tidak Setuju & Count & 17 & 13 & 30 \\
\hline & & $\%$ within RERATA_PD & $56.7 \%$ & $43.3 \%$ & $100.0 \%$ \\
\hline & & \% within KEPUTUSAN & $42.5 \%$ & $21.7 \%$ & $30.0 \%$ \\
\hline & & $\%$ of Total & $17.0 \%$ & $13.0 \%$ & $30.0 \%$ \\
\hline & Cukup Setuju & Count & 5 & 5 & 10 \\
\hline & & $\%$ within RERATA_PD & $50.0 \%$ & $50.0 \%$ & $100.0 \%$ \\
\hline & & $\%$ within KEPUTUSAN & $12.5 \%$ & $8.3 \%$ & $10.0 \%$ \\
\hline & & $\%$ of Total & $5.0 \%$ & $5.0 \%$ & $10.0 \%$ \\
\hline & Setuju & Count & 13 & 34 & 47 \\
\hline & & \% within RERATA_PD & $27.7 \%$ & $72.3 \%$ & $100.0 \%$ \\
\hline & & $\%$ within KEPUTUSAN & $32.5 \%$ & $56.7 \%$ & $47.0 \%$ \\
\hline & & $\%$ of Total & $13.0 \%$ & $34.0 \%$ & $47.0 \%$ \\
\hline & Sangat Setuju & Count & 2 & 7 & 9 \\
\hline & & $\%$ within RERATA_PD & $22.2 \%$ & $77.8 \%$ & $100.0 \%$ \\
\hline & & $\%$ within KEPUTUSAN & $5.0 \%$ & $11.7 \%$ & $9.0 \%$ \\
\hline & & $\%$ of Total & $2.0 \%$ & $7.0 \%$ & $9.0 \%$ \\
\hline \multirow[t]{4}{*}{ Total } & & Count & 40 & 60 & 100 \\
\hline & & \% within RERATA_PD & $40.0 \%$ & $60.0 \%$ & $100.0 \%$ \\
\hline & & \% within KEPUTUSAN & $100.0 \%$ & $100.0 \%$ & $100.0 \%$ \\
\hline & & $\%$ of Total & $40.0 \%$ & $60.0 \%$ & $100.0 \%$ \\
\hline
\end{tabular}

Berdasarkan hasil statistik deskriptif, dapat diketahui bahwa jumlah terbanyak adalah responden yang menyatakan setuju dengan memiliki keputusan tidak mengubah lahan. Hal tersebut menunjukkan bahwa penduduk yang memiliki place dependence tinggi tidak ingin merubah lahan. Untuk menguji hubungan secara lebih lanjut, Tabel 14 adalah hasil uji chi square yang dilakukan untuk mengetahui hubungan yang dihasilkan. 
Tabel 14. Deskripsi hubungan antara tingkat persetujuan place dependence dengan keputusan untuk mengubah lahan.

\begin{tabular}{|c|c|c|c|}
\hline & Value & df & Asymp. Sig. (2-sided) \\
\hline Pearson Chi-Square & $10.098^{a}$ & 4 & .039 \\
\hline Likelihood Ratio & 10.219 & 4 & .037 \\
\hline Linear-by-Linear Association & 9.566 & 1 & .002 \\
\hline $\mathrm{N}$ of Valid Cases & 100 & & \\
\hline
\end{tabular}

Berdasarkan hasil uji yang disajikan, dapat diketahui bahwa nilai signifikansi adalah 0,039, yaitu bernilai $<0,05$. Dengan demikian nilai tersebut menunjukkan bahwa $\mathrm{HO}$ ditolak atau terdapat hubungan antara tingkat persetujuan place dependence dengan keputusan untuk mengubah lahan. Kesimpulan yang diperoleh menunjukkan bahwa semakin tinggi rasa keterikatan tempat, semakin rendah keinginan untuk mengubah lahan sehingga alih fungsi lahan kemungkinan besar tidak akan terjadi. Hal tersebut disebabkan pemilik lahan telah merasa nyaman untuk melangsungkan aktivitas di dalamnya, melakukan intensitas aktivitas yang berlangsung cukup lama, dan merasakan manfaat yang diperoleh dari lahan tersebut.

\section{Kesimpulan}

Hasil penelitian di Kecamatan Pandaan adalah sebagai berikut:

a. Hubungan antara tingkat persetujuan pernyataan A. Saya merasa lebih puas tinggal di desa ini daripada di daerah lain terhadap Tingkat Pendapatan memiliki nilai signifikansi adalah 0,000*, yaitu bernilai <0,05. Dengan demikian nilai tersebut menunjukkan bahwa $\mathrm{HO}$ ditolak atau terdapat hubungan.

b. Hubungan antara tingkat persetujuan pernyataan B. Tidak ada tempat yang sebanding dengan desa ini terhadap lokasi melakukan aktivitas sehari-hari memiliki nilai signifikansi adalah 0,000*, yaitu bernilai <0,05. Dengan demikian nilai tersebut menunjukkan bahwa $\mathrm{HO}$ ditolak atau terdapat hubungan.

c. Hubungan antara tingkat persetujuan pernyataan C. Saya tidak ingin menggantikan aktivitas saya di desa ini untuk dilakukan di tempat lain terhadap lokasi melakukan aktivitas sehari-hari memiliki nilai signifikansi adalah 0,002, yaitu bernilai $<0,05$. Dengan demikian nilai tersebut menunjukkan bahwa $\mathrm{HO}$ ditolak atau terdapat hubungan.

d. Hubungan antara tingkat persetujuan pernyataan D. Melakukan aktivitas di desa ini lebih penting daripada melakukan di tempat lain memiliki nilai signifikansi adalah $0,000 *$, yaitu bernilai $<0,05$. Dengan demikian nilai tersebut menunjukkan bahwa HO ditolak atau terdapat hubungan.

e. Hubungan antara tingkat persetujuan pernyataan E. Desa ini adalah desa yang terbaik untuk melangsungkan aktivitas saya terhadap luas lahan yang dimiliki memiliki nilai signifikansi adalah 0,001, yaitu bernilai <0,05. Dengan demikian nilai tersebut menunjukkan bahwa $\mathrm{HO}$ ditolak atau terdapat hubungan.

f. Secara keseluruhan, hubungan antara tingkat persetujuan place dependence dengan keputusan untuk mengubah lahan memiliki nilai signifikansi adalah 0,039, yaitu bernilai $<0,05$. Dengan demikian nilai tersebut menunjukkan bahwa HO ditolak atau terdapat hubungan. 


\section{Referensi}

[1] Giuseppina S 2012 Urbanization strategies, rural development and land use changes in China: a multiple-level integrated assessment Land Use Policy 291 pp 165-78 DOI: 10.1016/j.landusepol.2011.06.003

[2] Verburg P H, Crossman N, Ellis E C, Heinimann A, Hostert P, Mertz O et al 2015 Land system science and sustainable development of the earth system: A global land project perspective Anthropocene 12 pp 29-41 DOI: 10.1016/j.ancene.2015.09.004

[3] Brown G dan Raymond C M 2007 The relationship between place attachment and landscape values: Toward mapping place attachment Applied Geography 272 pp 89-111 DOI: 10.1016/j.apgeog.2006.11.002

[4] Williams D R dan Vaske J J 2003 The Measurement of Place Attachment: Validity and Generalizability of a Psychometric Approach Forest Science 496 pp 830-40 Diakses dari

https://www.researchgate.net/publication/233712735_The_Measurement_of_Plac e_Attachment_Validity_and_Generalizability_of_a_Psychometric_Approach

[5] Pitriyani 2013 Kecamatan Pandaan Sebagai Kawasan Strategis Kabupaten Pasuruan Dalam Mendorong Pertumbuhan Ekonomi Daerah (Studi Pada Kecamatan Pandaan Dan BAPPEDA Kabupaten Pasuruan) Jurnal Administrasi Publik 17 Diakses dari http://administrasipublik.studentjournal.ub.ac.id/index.php/jap/article/view/215

[6] Prayitno G, Dinanti D, Rusmi S A, Surjono, dan Maulidatuz Z D 2019 Place Attachment Index of Landowners in Pandaan Sub-District, Pasuruan Regency, Indonesia IOP Conf. Series: Earth and Environmental Science 239012045 pp 1-8 Diakses dari https://iopscience.iop.org/article/10.1088/1755-1315/239/1/012045/meta

[7] Siddiq M I 2016 Dampak Pembangunan Jalan Tol Gempol-Pandaan terhadap Masyarakat Petani yang Lahannya Dibebaskan di Kecamatan Pandaan Kabupaten Pasuruan Swara Bhumi 120 pp $141-9$ Diakses dari https://jurnalmahasiswa.unesa.ac.id/index.php/swara-bhumi/article/view/15212

[8] Sandy I M 1980 Masalah Tata Guna Tanah - Tata Lingkungan di Indonesia (Jakarta: Jurusan Geografi Universitas Indonesia)

[9] Sugiyono 2012 Metode Penelitian Bisnis (Bandung: Alfabeta)

[10] Riduwan 2010 Skala Pengukuran Variabel-Variabel Penelitian (Bandung: Alfabeta) 